\title{
МІСЦЕ ПРАВОВОЇ ДОКТРИНИ У СТРУКТУРІ ПРАВОСВІДОМОСТІ
}

Старикова С. І.

У науковій статmі досліджена проблема визначення місця й ролі правової доктрини у структурі правосвідомості, проведений аналіз найбільш поширених підходів до їі структурування. Запропоновано розглядати правову доктрину як найбільш аргументований, несуперечливий, об'єктивний, стійкий складник наукового рівня правової ідеології як структурного компонента правосвідомості. Наведено сутнісні властивості та функції правової доктрини, ї спільні риси з іншими елементами правосвідомості.

Ключові слова: правова доктрина, правова ідеологія, правова психологія, правосвідомість, правова система.

В научной статье исследована проблема определения места и роли правовой доктрины в структуре правосознания, сделан анализ наиболее распространенных подходов $к$ ее структурированию. Предложено рассматривать пра вовую доктрину как наиболее аргументированную, непротиворечивую, объективную, устойчивую составляющую научного уровня правовой идеологии как структурного компонента правосознания. Приведены сущностные свойства и функции правовой доктрины, ее общие черты с другими элементами правосознания.

Ключевые слова: правовая доктрина, правовая идеология, правовая психология, правосознание, правовая система.

Starykova S. I. The place of legal doctrine in the structure of legal consciousness

The article is devoted to the question of determining the place and role of legal doctrine in the structure of legal consciousness. In order to solve aforementioned problem, the place of legal consciousness in legal system is considered. It is noted that legal consciousness is a phenomenon that has a complex structure, which is associated with the influence of various factors of legal reality and the performance of many functions. The existing approaches to the structuring of legal consciousness are considered, among which the most common is the conditional division of legal consciousness into legal psychology and legal ideology. Given the separation in the structure of legal ideology of ordinary, professional and scientific levels, the author proposes to consider legal doctrine as the most reasoned, consistent, objective, stable component of the scientific level of legal ideology. The common features of legal doctrine and other components of legal consciousness, including the influence of many objective factors, their identification and formulation of needs and interests of man and society, their reflection of legal reality, based on a system of values, regulatory, predictive, integrating legal system nature. The specific properties of legal doctrine that distinguish it from other components of legal consciousness are formulated, including: combination in legal doctrine of legal, scientific and philosophical forms of public consciousness; argumentation, structure and consistency of provisions; predominance in legal doctrine of intellectual components of legal consciousness; high level of theoretical and practical value; insignificant tendency of doctrinal legal consciousness to deformation. The functions of legal doctrine are revealed through the prism of the main functions of legal consciousness - cognitive, evaluative, regulatory, educational, prognostic, and heuristic. The directions of mutual influence of legal doctrine and non-doctrinal components of legal consciousness are outlined. It is concluded that legal doctrine forms the highest level of legal conscious.

Key words: legal doctrine, legal ideology, legal psychology, legal consciousness, legal system.

Постановка проблеми та її актуальність. Правосвідомість і правова доктрина $є$ взаємопов'язаними елементами правової системи, які значно впливають на процес правового регулювання суспільних відносин. Ці явища правової дійсності $є$ спорідненими, оскільки становлять ідеальну компоненту правової системи, й водночас різнопорядковими, відповідно до того рівня, який вони посідають у структурі правової системи. Варто зазначити, що обсяг поняття «правова доктрина» $\epsilon$ значно вужчим порівняно з обсягом поняття «правосвідомість», оскільки охоплює ті явища правової дійсності, які володіють низкою специфічних рис. Таким чином, правосвідомість співвідноситься із правовою доктриною як ціле та його частина.

Актуальність з'ясування місця правової доктрини у структурі правосвідомості зумовлюється необхідністю формулювання характерних властивостей правової доктрини та визначення їі ролі в розрізі правосвідомості та правової системи загалом. Аналіз співвідношення правової доктрини та інших структурних елементів правової свідомості надасть можливість у порівняльному аспекті сформулювати ключові риси та функції доктринальних положень, оцінити значення доктрини для правової системи загалом та окремих її елементів зокрема.

Аналіз останніх досліджень і публікацій. Проблема правової доктрини знаходиться у сфері наукових інтересів таких вітчизняних та зарубіжних авторів, як С.В. Батуріна, А.О. Васильєв, С.В. Васильєв, О.О. Зозуля, М.В. Кармаліта, Є.О. МадаєВ, Є.Ю. Полянський, Р.В. Пузиков, І.В. Семеніхін, В.М. Сирих, тощо. Питанню різних аспектів правосвідомості значну увагу приділяли С.С. АлексєєВ, М.М. Вопленко, І.О. Ільїн, Г.П. Клімова, Н.Ю. Коваленко, А.І. Луцький, Т.В. Михайліна, П.М. Рабінович та інші дослідники. Проте проблема 3'ясування місця й ролі правової доктрини у структурі правосвідомості залишається нерозв'язаною.

Метою статті $\epsilon$ спроба визначити місце правової доктрини у структурі правосвідомості через співвідношення із правовою ідеологією та крізь призму їі ознак, функцій та форм взаємодії з іншими компонентами правосвідомості.

Виклад основного матеріалу. Правова свідомість $\epsilon$ системним явищем, яке складається з елементів, пов'язаних між собою структурно, функціонально та генетично. Зі свого боку, правосвідомість $\epsilon$ частиною правової системи, яка виступає найбільш абстрактним інтегративним поняттям, що відображає і складники правової реальності, і правовий ідеал. 
Вплив правової системи на правосвідомість окремої людини, соціальної групи чи суспільства загалом $€$ очевидним, оскільки правосвідомість віддзеркалює всі правові явища, оцінюючи їх крізь призму правових ідеалів та цінностей. Проте правова свідомість також справляє зворотній вплив, виступаючи тією сферою, де формулюються та сприймаються правові цінності, викристалізовуються правові ідеї та принципи, встановлюються правові зв'язки між суб'єктами, формуються настанови щодо юридично значущої поведінки. На первинності правосвідомості наголошував І.О. Ільїн, стверджуючи, що «сама сутність, сама природа права в тому, що воно твориться свідомими істотами і для свідомих істот, мислячими суб'єктами і для мислячих суб'єктів» [1, с. 24]. Вплив правосвідомості на правову систему об'єктивується у правовідносинах, а також у законодавстві, правозастосовній, інтерпретаційній, контрольній та інших видах юридичної діяльності. Оскільки правова доктрина $\epsilon$ складником правосвідомості, все вищезазначене стосується її в повному обсязі. Наразі доречним буде навести характеристику правосвідомості, визначити ії поняття та структуру.

Незважаючи на значущість проблеми правової свідомості, загальноприйнята в наукових колах дефініція цього поняття відсутня, що, однак, не $\epsilon$ дивним. По-перше, правосвідомість $€$ явищем правової дійсності, яке проникає абсолютно в усі сфери правового життя, $є$ комплексним поняттям, що має значний обсяг та складну структурну будову. По-друге, правосвідомість $€$ багатоаспектним компонентом правової системи, котрий виконує різноманітні функції, сприймає влив різних явищ правової дійсності та здійснює на них зворотній вплив.

Розглянемо декілька запропонованих ученими підходів до визначення правосвідомості. На думку Ю.Ю. Калиновського, «правосвідомість - це сукупність оціночних думок та настанов, які визначають ставлення суб'єктів соціальних відносин (соціальних груп, страт, окремого громадянина або суспільства загалом) до права й чинного законодавства, а також практика його застосування, правових (або неправових) звичаїв, ціннісних орієнтацій, котрі регулюють людську поведінку в юридично значущих ситуаціях» [2, с. 12]. Г.П. Клімова під правосвідомістю розуміє «сукупність правових уявлень, почуттів, переконань, оцінок, що виражають ставлення індивідів, соціальних груп, суспільства загалом до права, до поведінки людей у галузі правового регулювання» [3, с. 40]. За переконанням М.М. Вопленка, «правосвідомість $\epsilon$ форма ідейно-психологічного відображення та освоєння правової дійсності через систему нормативно-оціночних уявлень і суджень людей про природу та закономірності правових явищ» [4, с. 13]. Н.Ю. Коваленко визначає правосвідомість як “сукупність поглядів, настроїв, теорій та ідей, які відображають не всю, а тільки суспільну дійсність, але не в повному обсязі, а лише ту сторону суспільної дійсності, котра охоплюється державно-правовими зв'язками та відносинами» [5, с. 41].

Таким чином, у найбільш загальному розумінні правова свідомість $\epsilon$ системою інтелектуальних (ідеологічних) та емоційно-вольових (психологічних) компонентів суспільної, групової чи індивідуальної свідомості, котрі відображають, оцінюють та перетворюють правову дійсність, а також регулюють поведінку людей у правовій сфері, виступаючи сполучною ланкою між правовими ідеями та їх утіленням у правовій системі, а також між об'єктивним правом та його реалізацією в суспільних відносинах.

Характеризуючи структурний аспект правосвідомості, варто зазначити, що поділ останньої на окремі компоненти $€$ досить конвенційним і викликаний радше методологічною потребою розмежування складників правосвідомості, аніж реальним, об'єктивним станом речей. На думку С.С. Алексєєва, структурні елементи правосвідомості - «це лише підрозділи більш-менш організованої сукупності, і за своєю суттю скоріше свідчення роз'єднаності правосвідомості» [6, с. 201]. Правосвідомість $\epsilon$ сукупністю (на противагу системі) правових поглядів, ідей, концепцій, категорій, почуттів, уявлень та інших явищ духовної сфери, які постійно взаємодіють між собою й можуть існувати в чистому вигляді лише теоретично. Яскравим доказом цієї тези $\epsilon$ існування такого структурного компонента правової свідомості, як переконання. Правові переконання $\epsilon$ нерозривним поєднанням чуттєвого та раціонального компонентів у духовній сфері людини. Вони базуються на логічному доведенні істинності певних правових положень, котрі підкріплюються та підсилюються почуттям упевненості в їх правильності та справедливості. Такий сплав розуму та почуття у правовій сфері i являє собою переконання. Однак логічне виокремлення структурних компонентів правосвідомості має великого теоретичного значення.

У науці $є$ багато підходів до структурування правосвідомості. Г.П. Клімова запропонувала виокремити у структурі правової свідомості раціонально-ідеологічний, емоційно-психологічний та настаново-поведінковий компоненти [3, с. 39]. Перші два складники за своїм змістовим наповненням збігаються із правовою ідеологією та психологією відповідно. Настаново-поведінковий компонент, на думку автора, «становлять правові настанови й відповідні стереотипи поведінки, які сприяють переведенню уявлень і цінностей у площину практичної реалізації» [3, с. 40]. А.І. Луцький загалом поділяє позицію Г.П. Клімової, зазначаючи, що структурно правосвідомість охоплює правову психологію, правові поведінкові фактори та правову ідеологію [7, с. 77-78]. Незаперечуючи справедливість наведених підходів, варто зазначити, що виділення поведінкового складника як самостійного компонента правосвідомості поряд із правовою психологією та ідеологією потребує певних уточнень. Хоча предмет психології й досі залишається дискусійним питанням, досить поширеною $є$ думка про поведінку як складник предмета психологічної науки (зокрема, виділяють біхевіоризм як системний підхід до вивчення поведінки людей). Крім того, психологія досліджує такі прояви людської психіки, як відхилення та психічні аномалії в поведінці особистості, конфліктна поведінка, поведінка особистості в особливих ситуаціях, тощо. Зважаючи на це, більш обґрунтованим видається поділ правосвідомості на правову ідеологію та правову психологію (яка, зі свого боку, містить емоційно-вольові та поведінкові компоненти).

Правова психологія - це сукупність емоцій, почуттів, уявлень, переживань, настанов, побажань та інших психічних явищ, що відображають ставлення суб'єкта до правової дійсності. Процеси, котрі відбуваються в межах правової психології людей та їх колективів, характеризуються стихійністю та малою передбачу- 
ваністю, оскільки містять ірраціональні компоненти. Ії̈ носієм, «одиницею виміру» $\epsilon$ людина, тому явища правової психології мають суб'єктивний, індивідуально-забарвлений характер і демонструють неповторність внутрішнього світу окремої особистості. Суб'єктами правової психології також можуть бути стійка або ситуативна група людей чи суспільство загалом. У таких колективах часто панують спільні для багатьох людей настрої та переживання. Водночас складники правової психології $\epsilon$ невіддільними від сфери раціонального, виступаючи однією з умов формування правових принципів та ідей. Такими психологічними явищами $\epsilon$, наприклад, почуття справедливості, прагнення до рівності між людьми тощо.

Правова ідеологія, зі свого боку, $\epsilon$ теоретичним узагальненням фактів правової дійсності. Вона являє собою сукупність абстрактних положень, понять, категорій, ідей, теорій, концепцій, доктрин, які цілеспрямовано й об'єктивно відображають, оцінюють правову дійсність та впливають на неї. Зазначені компоненти правової ідеології відрізняються науковим характером положень, їх доказовістю, практичною застосовністю.

Науковий характер правової ідеології не означає, що іiі носіями $є$ виключно науковці. Елементи правової ідеології пронизують буденну і професійну правосвідомість через здатність людини до абстрактного мислення, сприйняття та узагальнення правової інформації. Кожна людина володіє та оперує хоча б найбільш поширеними правовими категоріями (такими, наприклад, як право, законність, правосуддя, правочин, спадкування, кримінальна відповідальність тощо). І хоча обсяг знань у різних суб'єктів не збігається, будь-яка особа з нормальними інтелектуальними здібностями не тільки емоційно сприймає правову дійсність, а й раціонально пізнає та оцінює їі. А.І. Луцький зазначає, що правова ідеологія має такий самий ступеневий розподіл, як і правосвідомість загалом. Крім того, він наголошує, що «різниця полягає в тому, наскільки раціональними й науковообґрунтованими виступають усвідомлені правові ідеї, цінності, концепції, уявлення, принципи тощо» [7, с. 87]. Отже, класифікацію правосвідомості на побутову, професійну та наукову не варто ототожнювати з ії структурним поділом на правову психологію та правову ідеологію. У першому разі має місце суб'єктний критерій, у другому - якісний.

Подібно до правової свідомості загалом, правова ідеологія як її складник охоплює побутовий, професійний i науковий рівні. Зі свого боку, в межах наукового рівня правової ідеології пропонується виокремити власне науковий рівень та правову доктрину. Остання утворює найвищий рівень правової ідеології та $є$ найбільш аргументованою, переконливою, несуперечливою, статичною, практично й теоретично цінною частиною правосвідомості. Правова доктрина $є$ квінтесенцією всього інтелектуального потенціалу правової свідомості.

Як структурний компонент правосвідомості, правова доктрина містить усі їі сутнісні ознаки. Проте вона відрізняється і специфічними властивостями. Надалі проаналізуємо найбільш істотні спільні риси правової доктрини та інших компонентів правосвідомості (правової психології та недоктринальних складників правової ідеологіï).

По-перше, правова доктрина і правосвідомість загалом як системні явища формуються, розвиваються, функціонують та змінюються під впливом об'єктивних факторів - економіки, технологій, політики, культури, освіти, науки, релігії та навіть мистецтва. До вагомих чинників впливу на правосвідомість М.Є. Черкас цілком справедливо відносить право та законодавство [8, с. 178]. На значущості економічних та політичних складників робить акцент М.М. Вопленко [4, с. 6]. У контексті правової доктрини як складника правосвідомості маємо наголосити не тільки на впливі зазначених факторів, але й на зворотній дії доктринальних положень на функціонування інших соціальних систем.

По-друге, правосвідомість і правова доктрина $є$ способом виявлення, оцінювання та формулювання різноманітних потреб та інтересів людини та суспільства. Право $\epsilon$ найбільш концентрованою та стійкою формою вираження соціальних запитів і своїм існуванням завдячує людській здатності мати соціальні, духовні, економічні, фізичні потреби та трансформувати їх у конкретні вимоги щодо їх реалізації.

По-третє, правова доктрина та інші компоненти правосвідомості з тією або іншою мірою достовірності відображають правову реальність та всі елементи правової системи, які становлять іiї безпосередній об'єкт. Правосвідомість $€$ універсальним інструментом пізнання, оцінювання та перетворення правової дійсності. Таке пізнання може бути активним або пасивним. Пасивне відображення правової дійсності відбувається тоді, коли суб'єкт сприймає правову інформацію стихійно, не зіставляє ії з гуманістичними цінностями, що часто $\epsilon$ справедливим щодо буденного рівня правосвідомості. Правова доктрина як складник правосвідомості відповідно до свого призначення має активно і творчо відображати правову дійсність, оперативно реагувати на розвиток суспільних відносин та соціальні запити щодо їх правового регулювання. Крім того, відображення правової дійсності за посередництвом правосвідомості умовно можна класифікувати на таке, яке містить значні суб'єктивні елементи й таке, що наближається до об'єктивності. Правова доктрина як найбільш достовірне й несуперечливе знання завжди прагне до об'єктивності, хоча про збіг доктринальних положень й усіх аспектів правової дійсності говорити можна лише умовно.

По-четверте, спільною ознакою правової доктрини та інших компонентів правосвідомості $\epsilon$ те, що вони завжди базуються на системі цінностей. Правові цінності зумовлюються природою людини, їі потребами та цілями. Правосвідомість, виконуючи евристичну функцію, виводить ті ознаки, принципи, цілі, ідеали, цінності правової системи, які відповідають природі людини як біосоціальної істоти. Правова доктрина як складник правосвідомості ґрунтується на уявленнях про потреби та природні права людини, характер правової системи і їі нормативної основи. Доктринальна правосвідомість сприяє формулюванню та висуненню вимог до правової дійсності, які в науковій літературі прийнято називати правовим ідеалом. Окремі дослідники навіть називають їі формою правового ідеалу (поряд із правовими теоріями та концепціями праворозуміння) [9, с. 111].

По-п'яте, із ціннісного характеру правосвідомості (зокрема правової доктрини) випливає іï нормативно-регулятивний характер. Відповідно до поширеної в науковій літературі думки «регулятивна функція пра- 
восвідомості зводиться до перероблення і трансляції інформації про об'єктивні ознаки права, а також до предметного втілення цього знання в конкретні вчинки та дії» [10, с. 177]. У дещо спрощеному вигляді регулятивний вплив правової свідомості здійснюється так. Суб'єкт через необхідність у врегулюванні суспільних відносин пізнає певний фрагмент правової дійсності (правові норми, джерела права, усталену практику реалізації права тощо), оцінює його відповідно до «шкали» правових цінностей i, відповідно, обирає варіант власної поведінки, котрий задовольняє або не задовольняє вимогам права. Правова доктрина, на відміну від інших складників правосвідомості, здійснює не прямий, а опосередкований нормативно-регулятивний вплив на правові відносини та поведінку суб'єктів. Він здійснюється за допомогою тих компонентів правової системи, які зазнали впливу доктринальних ідей (принципи права, законодавство, юридична практика тощо). Доктрина, крім того, регулює відповідні види юридичної діяльності, висуваючи вимоги до їі змістовних та процедурних аспектів і надаючи правовим актам, що $є$ результатами такої діяльності, науково обґрунтованого характеру.

Правова доктрина, як й інші складники правосвідомості, має прогностичний характер. Спираючись на дані про стан національної правової системи, іï взаємозв'язки з іншими правовими системами, правосвідомість виступає інструментом передбачення тих тенденцій, котрі побутуватимуть у майбутньому. Правова доктрина піднімає прогнозування на найвищий науковий щабель, сприяє прогресивним змінам у правовій системі, її погодженню з рівнем розвитку суспільних відносин.

Завершуючи розгляд спільних ознак правової доктрини та інших компонентів правосвідомості, не можна оминути увагою їх інтегруючий щодо правової системи характер. Правосвідомість $€$ тим універсальним фактором, який у той або інший спосіб впливає на абсолютно всі сфери правової реальності, і навіть більше визначає їх характер. Не випадково з англійської мови поняття правової свідомості дослівно перекладається як «почуття справедливості» ("sense of justice”).

Правова доктрина, крім спільних ознак, має також специфічні риси, що суттєво відрізняють їі від нетотожних елементів правової ідеології та психології.

По-перше, особливість правової доктрини полягає в тому, що вона $€$ комбінацією правової, наукової та філософської форм суспільної свідомості. Недоктринальні компоненти правової ідеології мають схожу структуру із правовою доктриною, проте відрізняються меншим ступенем узгодженості, достовірності та авторитетності положень, більш поширеними $\epsilon$ прояви суб'єктивності суджень і висновків. Правова психологія, зі свого боку, поєднує різноманітні форми суспільної свідомості (власне правову, моральну, політичну, релігійну тощо) й із цього погляду $є$ синкретичною.

По-друге, доктринальна правосвідомість характеризується домінуванням у їі структурі інтелектуальних елементів структури свідомості (правові знання, правове мислення, праворозуміння). На противагу доктрині, у складі правової психології переважають емоційні та вольові компоненти. Необхідно зазначити, що ця ознака $є$ спільною і для правової доктрини, і для правової ідеології через абстрактний, раціональний характер положень останньої.
По-третє, правова доктрина відрізняється значною структурованістю, системністю, узгодженістю та несуперечливістю положень. Якщо в межах правової ідеології можна знайти багато розрізнених наукових поглядів, дискусійних питань, то доктринальні позиції $\epsilon$ загальновизнаними серед науковців та юристів-практиків, $\epsilon$ більш стійкими до змін і зовнішніх впливів. Правова психологія $\epsilon$ ще більш несистематизованим утворенням правової свідомості.

По-четверте, специфічною ознакою правової доктрини $\epsilon$ їі носії. Їх можна класифікувати на осіб, які $\epsilon$ виробниками доктринальних ідей, та матеріальні носії, що слугують зовнішньою формою втілення доктринальної інформації. До першої групи належать визнані вчені, наукові школи, а також суб'єкти правозастосування та правотлумачення, однак не всі, а тільки ті, які у процесі своєї діяльності формують доктринальні підходи до вирішення практичних завдань (наприклад, судді Конституційного Суду). Другу групу носіїв утворюють наукові публікації та видання, серед яких - монографії, статті, підручники, посібники, коментарі законодавства, збірники наукових праць, у яких фіксуються доктринальні положення. Проте найчастіше правова доктрина існує в нематеріальній формі, втілюючись в ідеях, підходах, категоріях, судженнях, конструкціях. Єдиними ж носіями правової психології $є$ будь-які особи або людські колективи. Власне, правова ідеологія, зокрема юридична наука, за критерієм носіїв дещо схожа з доктриною. Різниця полягає у ступені наукової підготовки цих осіб, теоретичної обґрунтованості, авторитетності ідей та положень, які містяться в наукових працях.

По-п'яте, однією з головних відмінностей доктринальних ідей $\epsilon$ характер та ступінь їх практичної цінності. Якщо значення правової психології полягає в безпосередньому сприйнятті людиною правової реальності, формуванні правових настанов, первинному регулюванні поведінки особи, а правової ідеології - у висуненні й обґрунтуванні певних правових ідей, формуванні понять, узагальненні емпіричних даних правової дійсності, то правова доктрина, котра зароджується в юридичній науці, опосередковано, але значно впливає на правове регулювання суспільних відносин. Цей вплив здійснюється через нормотворчу, правозастосовну, інтерпретаційну, правоохоронну та іншу діяльність органів державної влади та безпосередню реалізацію норм права його суб'єктами (наприклад, під час укладення цивільно-правових договорів). Варто додати, що правова доктрина впливає не лише на різні види юридичної діяльності, але й на правову освіту. Загальновизнані доктринальні ідеї та підходи лежать в основі викладання правових дисциплін на юридичних факультетах та в юридичних закладах вищої освіти.

По-шосте, правова доктрина в її належному стані як найвищий щабель правосвідомості за визначенням не може зазнавати змістових деформацій. Під належним станом у цьому контексті розуміється високий рівень об'єктивності, доказовості, узгодженості доктринальних положень та сприйняття правовою доктриною загальновизнаних правових цінностей. Відповідно до поширеної в науковій літературі думки деформацією правосвідомості $\epsilon$ сукупність негативних змін структурних елементів правової свідомості, які відбуваються під впливом внутрішніх та зовнішніх факторів, унаслі- 
док яких правосвідомість набуває ознак відхилення від соціально-прийнятної норми та спричиняє негативні суспільні наслідки. Особливу небезпеку несуть професійна деформація юристів-практиків та деформація правосвідомості науковців, оскільки саме від них залежить стан правової сфери в суспільстві, рівень захисту прав і свобод людини. Доктринальний рівень правосвідомості, відповідно до свого характеру та призначення, не може й не повинен зазнавати жодних деформацій. Однак насправді трапляються доктрини, сприйняті в минулому чи нині суспільною й державною практикою, які не відповідають уявленням про належне у правовій сфері (наприклад, можна навести політико-правову доктрину фашизму). Проте оскільки випадки деформації доктринальної правосвідомості $\epsilon$ скоріше виключенням, аніж правилом, маємо констатувати таку ознаку правової доктрини, як стійкість до деформацій та орієнтація на загальновизнані правові цінності.

Розвиваючи проблематику правової доктрини в розрізі правосвідомості, не можна оминути увагою ї функціональний аспект. Більшість авторів наукових досліджень, присвячених питанням правосвідомості, виокремлюють три «класичні» функції правосвідомості: пізнавальну, оцінну та регулятивну, котрі відповідають трьом етапам опанування людиною правової дійсності. М.М. Вопленко додає до цього переліку також виховну функцію правосвідомості, яка полягає в тому, що «виступає елементом духовної культури суспільства та особистості, слугує ідейно-психологічним засобом виховання свідомого та відповідального ставлення людей до життя» [4, с. 37-38]. Можна цілком погодитись із виокремленням виховної функції правосвідомості, котра створює культурно-ціннісний фундамент правових знань та правової поведінки особистості, їі ставлення до правових феноменів, певним чином інтегруючи інші три функції в єдине ціле. А.І. Луцький як функції правової ідеології як складника правосвідомості пропонує розглядати цілевизначення та прогнозування, котрі «закладають вектор розвитку правової системи держави для цілеспрямованого руху до прогресу» $[7$, с. 83].

Основні функції правосвідомості знаходять свою конкретизацію та специфічне втілення у правовій доктрині:

1. Пізнавальна функція правосвідомості за посередництвом правової доктрини реалізується через з'ясування сутності правових явищ, ретельне осмислення правової реальності за допомогою наукових методів. Результатом доктринального осягнення правової дійсності $\epsilon$ достовірне систематизоване наукове знання у вигляді підходів, принципів, понять, категорій, правових конструкцій тощо.

2. Оцінна функція правової доктрини як складника правосвідомості передбачає зіставлення правової реальності із сформульованими юридичною наукою правовими цінностями та ідеалами. Метою такого оцінювання $\epsilon$ не формулювання суб'єктивної думки щодо переваг чи недоліків правової системи, а аргументована критика різних іiі компонентів та висунення науково обґрунтованих пропозицій щодо їх вдосконалення.

3. Регулятивна функція правової доктрини в розрізі правосвідомості полягає у впровадженні правових ідеалів, ціннісних орієнтацій та наукових напрацювань у нормотворчу, правозастосовну, інтерпретаційно-пра- вову та інші види юридичної діяльності з метою вдосконалення правової реальності.

4. Виховна функція правової доктрини втілеюється у впливі доктринальних положень юридичної науки на правову освіту та загальний культурний розвиток населення. Виховний вплив реалізується через прищеплення соціально корисних правових переконань, мотивів та моделей поведінки, підвищення рівня правових знань та навичок, формування в особи базових уявлень про ціннісні підстави права.

5. За посередництвом прогностичної функції правової доктрини як складника правосвідомості відбувається висунення наукових гіпотез про напрями майбутнього розвитку правової системи, найбільш вірогідні параметри змін правової реальності (характер, швидкість, глибина трансформаційних процесів тощо). Такі гіпотези самі собою не утворюють доктрини, оскільки $\epsilon$ лише вірогідним знанням. Проте вони походять саме з доктринальних положень про основні закономірності формування, розвитку та функціонування правової системи.

6. Евристична функція правової доктрини проявляється у відкритті раніше невідомих, проте об'єктивно існуючих правових явищ, процесів та закономірностей.

Завершуючи розгляд правової доктрини як складника правосвідомості, необхідно проаналізувати взаємовплив цих правових явищ. Правова доктрина як частина правової ідеології та інші складники правової свідомості характеризуються багаторівневою взаємодією, в межах якої можна виділити такі напрями:

1. Правова психологія та правова ідеологія впливають на правову доктрину, забезпечуючи ії емпіричним і теоретичним матеріалом для доктринальних досліджень і виступаючи іï першоджерелом, певними етапами розвитку і вдосконалення.

2. Правова доктрина сприяє розвитку правосвідомості й підвищенню загального рівня правової культури суспільства через актуалізацію достовірного і практично спрямованого наукового знання про право.

3. Правосвідомість в окремих випадках стає об'єктом або предметом доктринальних розробок у сфері права. Наявний рівень правової свідомості й культури, їх вплив на правове життя суспільства, необхідність удосконалення правової свідомості загалом та їі конкретних елементів зокрема спонукають науковців шукати відповіді на ці питання.

Висновки. Розглянувши основні риси, функції, місце правової доктрини в розрізі правосвідомості, іiі співвідношення із суміжними поняттями, можемо підсумувати таке:

1. Правосвідомість $€$ невід'ємним складником правової системи суспільства, який сприяє їі інтеграції в єдине ціле. Правова доктрина становить найвищий рівень правової свідомості.

2. Правова доктрина має як спільні риси, що об'єднують їі з іншими складниками правосвідомості (правовою психологією та недоктринальними складниками правової ідеології), так і специфічні ознаки, котрі вирізняють її з-поміж них.

3. Основні функції правової свідомості знаходять своє специфічне втілення у функціях правової доктрини.

4. Правова доктрина впливає на формування й розвиток усіх рівнів правосвідомості, які, зі свого боку, справляють на неї зворотний вплив. 


\section{Література}

1. Ильин И.А. О сущности правосознания / подготовка текста и вступительная статья И.Н. Смирнова. Москва : «Рарогъ», 1993. 235 с.

2. Правосвідомість і правова культура як базові чинники державо- творчого процесу в Україні : монографія / Л.М. Герасіна, О.Г. Данильян, О.П. Дзьобань та ін. Харків : Право, 2009. 352 с. URL: http://library.nlu.edu.ua/POLN TEXT/MONOGRAFII_2010/Daniljan_2009.pdf (дата звернення: 14.06.2020).

3. Клімова Г.П. Правосвідомість: до теорії питання. Актуальні питання інноваційного розвитку. 2012. № 2. C. 35-41. URL: http://nbuv.gov.ua/UJRN/apir_2012_2_8 (дата звернення: 14.06.2020).

4. Вопленко Н.Н. Правосознание и правовая культура: учебное пособие. Волгоград : Изд-во ВолГУ, 2000. 52 с.

5. Коваленко Н.Ю. Правова природа правосвідомості. Науковий вісник Міжнародного гуманітарного університету. Юриспруденція. 2013. Вип. 6-1(1). С. 40-43. URL: http://nbuv.gov.ua/UJRN/Nvmgu_jur_2013_6-1(1)_12 (дата звернення: 14.06.2020).

6. Алексеев С.С. Общая теория права : В 2-х т. Т.І. Москва : Юрид. лит. 1981. 360 с.
7. Луцький А.І. Правова ідеологія в українському державотворенні: теорія і практика : дис. ... д-р. ю. наук. Київ, 2015. 409 с.

8. Черкас М.Є. Чинники, що впливають на формування правосвідомості в Україні. Вісник Національної академії правових наук України. 2016. № 3. С. 172-182. URL: http://nbuv.gov.ua/UJRN/vapny_2016_3_28 (дата звернення: 14.06.2020).

9. Калітинський В.М. Правовий ідеал: філософсько-правовий аналіз. Європейські перспективи. 2016. Вип. 2. С. 111-115. URL: http://nbuv.gov.ua/UJRN/ evpe_2016_2_20 (дата звернення: 14.06.2020).

10. Філософія права : підручник. / О.Г. Данильян, О.П. Дзьобань, С.І. Максимов та ін. / за ред. д-ра філос. наук, проф. О.Г. Данильяна. Харків : Право, 2009. 208 c.

Старикова С. І., аспірантка кафедри теорії і філософії права Національного юридичного університету імені Ярослава Мудрого 